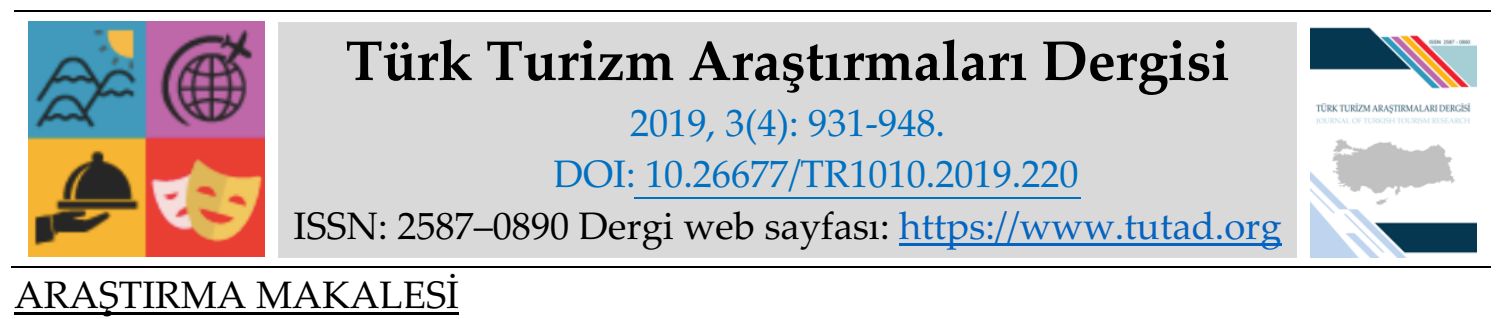

\title{
Festivaller ve Yerel Halk Üzerindeki Sosyal Etkileri: Urla Örneği
}

Arş. Gör. Dr. Pınar IŞILDAR, Dokuz Eylül Üniversitesi, Reha Midilli Foça Turizm Fakültesi, İzmir, e-posta: pinar.isildar@deu.edu.tr ORCID: https://orcid.org/0000-0001-7667-9951

Dr. Öğr. Üyesi, Özay YILDIZ, Dokuz Eylül Üniversitesi, Reha Midilli Foça Turizm Fakültesi, İzmir, e-posta: ozay.yildiz@deu.edu.tr ORCID: https://orcid.org/0000-0002-0777-8574

\section{Öz}

Turistik çekim unsuru olarak festivaller, ülkemizde, özellikle gelişmekte olan bölgelerde önemini gittikçe artırmaktadır. Ekonomik, çevresel ve sosyokültürel olumlu veya olumsuz etkileri barındıran festivallerin gelişmesi veya son bulmasında yerel halkın önemli bir payı bulunmaktadır. Bu çalışma, festivallerin yerel halk üzerindeki etkilerini, sosyal fayda ve sosyal maliyet kapsamında keşfetmeyi ve belirlenen etkilere göre yerel halkın memnuniyet düzeylerini koruyarak festivallerin sürekliliğinin sağlanması için öneriler getirmeyi amaçlamaktadır. Çalışma yıl boyunca çeşitli festivallere ev sahipliği yapan Urla ilçesinde gerçekleştirilmiştir. Gerçekleştirilen 32 görüşme içerik analizine tabi tutulmuş, bulgulara göre sosyal fayda ve sosyal maliyet faktörlerinin kapsaminda sosyal etkiler elde edilmiştir. Sosyal fayda faktörünün altında toplumsal ve kültürel/bireysel fayda alt faktörleri, sosyal maliyet faktörünün altında yaşam kalitesi alt faktörleri kapsamında etkiler keşfedilmiştir. Çalışmada ayrıca festivallerin zaman ve mekân içinde dağılmasının yerel halk tarafından desteklendiği ve olumsuz etkilerin azalmasında etkili olduğu tespit edilmiştir.

Anahtar Kelimeler: Festival, Yerel Halk, Sosyal Etkiler, Urla.

Makale Gönderme Tarihi: 17.06.2019

Makale Kabul Tarihi: 05.10.2019

\section{Önerilen Atıf:}

Işıldar, P. ve Yıldız, Ö. (2019). Festivaller ve Yerel Halk Üzerindeki Sosyal Etkileri: Urla Örneği, Türk Turizm Araştırmaları Dergisi, 3(4): 931-948.

(C) 2019 Türk Turizm Araştırmaları Dergisi. 


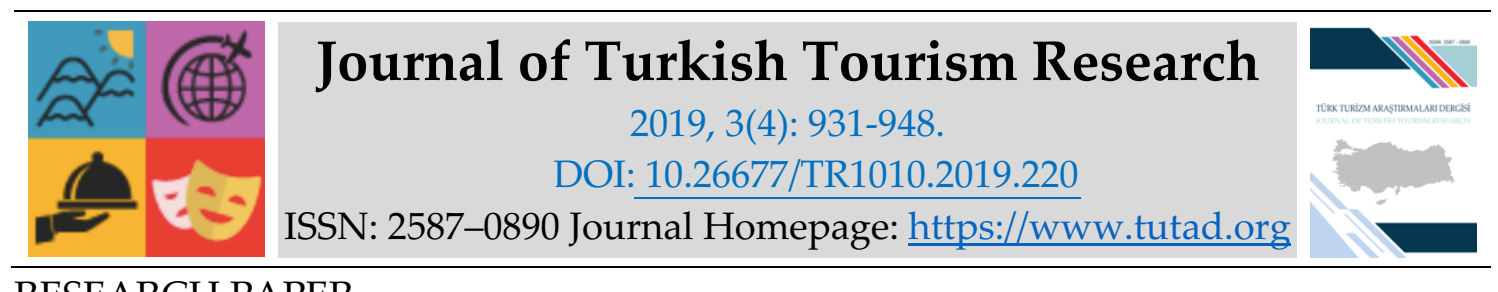

RESEARCH PAPER

\title{
Festivals and Their Social Impacts on Local Population: The Case of Urla
}

Dr. Pınar IŞILDAR, Dokuz Eylül University, Reha Midilli Foça Faculty of Tourism, İzmir, e-mail: pinar.isildar@deu.edu.tr ORCID: https://orcid.org/0000-0001-7667-9951

Assistant Prof. Dr. Özay YILDIZ, Dokuz Eylül University, Reha Midilli Foça Faculty of Tourism, İzmir, e-mail: ozay.yildiz@deu.edu.tr ORCID: https://orcid.org/0000-0002-0777-8574

\begin{abstract}
Festivals as tourist attractions are increasing in importance in Turkey, and especially in developing regions. The local population has a major role in the development or termination of festivals, which carry negative and positive impacts on the economy, environment and culture of the destination. The aim of this research is to explore the impacts of festivals on locals in the frame of social cost and benefit, and to provide implications for the continuation of festivals, while sustaining the locals' level of contentment, based on the determined impacts. The research is conducted in Urla, which hosts numerous festivals throughout the year. A total of 32 interviews were conducted and subjected to a content analysis and this resulted in determining certain socio-cultural impacts within the factors of social cost and benefit. According to the findings, impacts within the sub-factors of social and cultural / individual benefit under the social benefit factor, as well as sub-factors of quality of life under the social cost factor have been obtained. The research also concluded that spreading festivals across time and place is supported by the local population, which further reduces negative impacts.
\end{abstract}

Keywords: Festivals, Local Population, Social Impacts, Urla.

Received: 17.06 .2019

Accepted: 05.10.2019

\section{Suggested Citation:}

Iş1ldar, P. and Yıldız, Ö. (2019). Festivals and Their Social Impacts on Local Population: The Case of Urla, Journal of Turkish Tourism Research, 3(4): 931-948.

(C) 2019 Türk Turizm Araştırmaları Dergisi. 


\section{GíRiş}

Yerel halkın ziyaretçilerle etkileşimi ve genel olarak turizmle ilişkileri, çok sayıda değişken içeren, ayrıca zaman içinde değişen ve bu nedenle çok boyutlu olarak incelenmesi gereken bir konudur. Bölgeye gelen ziyaretçilerin, sayısı, geliş sıklığı, kalış süresi ve dönemselliği gibi nicel; ancak demografik özellikleri ve kültürel arka planları doğrultusunda baskın davranış özellikleri gibi nitel özelliklere ek olarak, arz kapasitesi ve işletmelerin davranışları, turistik ürünlerin yapısal özellikleri ve doğal olarak hedef bölgede sürekli yaşayan yerel halkın toplumsal özellikleri belirleyici unsurlardan en önemlileri olarak kendini gösterir (Olalı, 1990; İçöz vd., 2009). Ziyaretçiler ve yerel halk arasında olumlu kabul edilen bir etkileşim, ayrıca yerel halkta turizme yönelik olumlu tutum, iki taraf için de en yüksek tatmini ve turizmden beklenen faydayı sağlayan, arzu edilen durumdur.

Doğal olarak, ziyaretçi - yerel halk etkileşim sıklığının arttığı dönemlerde, turizmin toplumsal etkileri daha belirgin olacaktır. Festival dönemleri bu etkileşim sıklığının arttığı ve etkilerin açığa çıktığı önemli dönemlerdir. Yoğunluğun arttığı bu dönemlerde gözlemlenen sonuçlar olumlu veya olumsuz olarak, örneğin kalabalık ve artan trafik veya ekonomik fayda elde edilmesi (Olalı ve Timur, 1988), yerel halkın ziyaretçilere ve genel olarak turizme yaklaşımını değiştirebilir.

Bir veya birkaç gün içinde hedef bölgeye olağandışı yoğunlukta ziyaretin gerçekleşmesine neden olan festivallerin, yerel halk üzerinde normalin üzerinde ve daha kolay gözlemlenebilir etkileri bulunmaktadır. Festivallerin turizm olayı içerisinde önemi, getirileri açısından gün geçtikçe artmaktadır. Olumlu getirilerinin yansıra, yaşanacak yoğunluğun olumsuz getirilerinin de olması söz konusu olup, toplumları çeşitli şekillerde etkileyerek değişmelerine neden olabilmektedirler. Bu etkilerin neler olduğunu tespit edilmesi ve özellikle yerel halk tarafından kabul edilecek şekilde ele alınması turizm olayının önemli bir parçası olan festivallerin devamı ve gelişimi açısından önemlidir. (Delamere, 2001).

$\mathrm{Bu}$ çalışma, festivallerin yerel halk üzerindeki sosyal etkilerini keşfetmeyi amaçlamaktadır. Festivallerin sosyal etkilerinin ölçülmesinde, yerel halkın bu etkileri algılama biçimlerinin değişkenliği, ayrıca değişime yönelik toplumsal tutum ve algıların ölçümü yoluyla etkilerin belirlenmesi zorunluluğu nedenleriyle, genel-geçer bir ölçüm aracı yerine, örnek olaylarda yer alan yerel halkın sınırlarının çizilmesi, diğer paydaşların ve festivalin özelliklerinin belirlenmesi ve durumsal olarak incelenmesi önemli olmaktadır (Wilmersdörffer ve Schlicher, 2018).

Bu kapsamda, çalışma tek bir festivale odaklanmak yerine, yıl boyunca festivallerin sürdüğü hedef bölgenin ele alınmasıyla, yerel halkın sürekli gündelik yaşamı üzerindeki etkilere odaklanarak, aynı konuda gerçekleştirilen diğer çalışmalardan ayrılmaktadır. Derinlemesine inceleme fırsatı yaratan bu durum, literatürde var olan etkilere ek olarak yeni etkilerin keşfedilmesiyle, çalışmaya özgün bir değer katmaktadır. Bu doğrultuda, çalışma Urla örnek olayı çerçevesinde, Urla'da gerçekleştirilen festivaller kapsamında incelenmiştir. Araştırma evreni olarak Urla ilçesinin seçilmesinin nedeni, turizmin sosyal etkilerinin çok boyutlu ve uzun vadeli biçimde gerçekleşmesinden dolayı, tek bir festivalin etkililerinden ziyade, yıl içerisine yayılan birden fazla çeşitli festivallerin olması ve yerel halkın festivallerin neden olduğu etkileri yıl boyunca gözlemleyebilme olanağına sahip olmasıdır. Sosyal Etkilerin keşfedilmesinde ise gerçekleştirilen içerik analizinde, literatürde yer alan, festivallerin sosyal etkilerini ölçen çeşitli çalışmaların Sosyal Etki Ölçekleri incelenmiş, kodlama protokolünün geliştirilmesinde Delamere vd,. (2001) ve Delamere'in (2001) ölçeği dikkate alınmıştır. 


\section{TURIZM VE YEREL HALK}

Turizm sayesinde insanlar, hiç gitmeyecekleri yerlere gitmekte ve hiç tanışmayacakları insanlarla etkileşime girmektedirler. Böylece turizm, farklı toplumları ve kültürleri bir araya getiren, bu süreçte kendi kültürünü de yaratan sosyolojik bir olay halini alır (Günlü, 2007). Turistik etkileşimin gerçekleştiği hedef bölgede yaşayan yerel halkın yaşam süreçleri boyunca geliştirdikleri ve yaşattıkları alışkanlık, gelenek ve miras çevresinde biçimlenen yerel kültür, bölgeye gelen "yabancılara" maruz kalır (Usta, 2001). Dahası, bu yabancılar sürekli yaşadıkları bölgedeki toplumsal normlara uyma baskısından kurtuldukları, rekreasyon arayışında oldukları ve farklı satın alma örgüleri sergiledikleri için hedef bölgenin kültürü ile uyumsuz davranışlar sergileyebilir, hedef bölgenin yaşayış biçimlerini anlama ve takdir etme için gerekli arka plan ve zamandan yoksun olabilirler. Yerel halk, gündelik yaşamda kullandıkları alanlar ve kaynaklar için yabancılarla paylaşım, rekabet, hatta çatışma içine girebilir.

Turizmin, yerel halk ve onların yaşam biçimleri üzerindeki etkileri genelde olumlu / olumsuz olarak sınıflandırılır ve yerel halkın turizmin neden olduğu değişimi benimseme düzeyi ölçüt olarak kabul edilir (Mathieson ve Wall, 1982). Ancak burada iki sorun bulunmaktadır. Birincisi, turizmin sosyal etkileri, ekonomik etkilerde olduğu gibi sayısal ölçüme ve nesnel karşılaştırmaya elverişli değildir. İkincisi de ölçüt kabul edilen benimseme düzeyi, toplum içinde ve turistik gelişim sürecinde farklılıklar gösterir. Bu nedenlerle turizmin sosyal etkileri çok boyutlu ve uzun vadeli biçimde ele alınmalıdır.

Ziyaretçi ve yerel halkın etkileşim içinde bulunduğu turistik ortamın özellikleri, etkileşimin niteliği ve toplumsal etki düzeyi üzerinde belirleyicidir. Turistik ortam, hedef bölge içinde turistik etkinliğin belirgin biçimde gerçekleştiği alanı ifade eder ve turistik simgeler, durumlar ve bölgelerden meydana gelir. Turistik simgeler, ziyaretçinin seyahatine anlam katan unsurlardır ve bunların özgünlügünün algılanma biçimi turistik durumlar olarak ifade edilir (Doğan, 2004). Turistik bölgeler ise, ticari turistik etkinliğin gerçekleştiği, ya da turizme terk edilen "ön bölgeler" ve yerel halkın gündelik yaşam biçimini turizmden etkilenmeden sürdürdüğü, ya da turizmden korunan "arka bölgeler" olarak ikiye ayrılır. (MacCannell, 1974). Turistik etkinliğin bölgesel ve mevsimsel yoğunluğu ise, etkileşim miktarını belirleyerek, toplumsal etkilerin daha belirgin olmasına neden olmaktadır (Kozak vd., 2008). Artan yoğunluk, artan doluluk oranları ve ticari etkinlik yanında, kalabalık, trafik, suç oranları, gösteriş etkisi, doğal ve kültürel çevrenin yıpranması, dönemsel fiyat artışları ve enflasyonist baskılar, göç ve yabancı düşmanlığı gibi olumsuz etkilerin de oluşmasına ya da artmasına neden olabilir (Olalı ve Timur, 1988; İçöz, 2001). Özellikle doğal alanlar üzerinde oluşan yapılaşma baskısı ve inşaat spekülasyonu uzun vadede hedef bölgenin özgünlügü̈nü ve çekim unsurunu kaybederek kültürel peyzajının bozulmasına, sıradanlaşmasına ve kentleşmesine neden olabilir (Tuan, 1974; Olalı, 1990; Kuban, 2000). Buna karşılık, düşük sezonda yaşanan kapasite kaybı, eksik istihdam ve kamu yatırımlarında dengesizlik gibi sorunlar bu durumu daha da kötüleştirmektedir (Olalı vd., 1983).

Etkinliklerin uzun vadeli olumlu sonuçlar yaratması adına, taşıma kapasitesi, kabul edilebilir değişimin ölçütleri ve sürdürülebilir gelişimi merkezine alan, ziyaretçi ve işletmelerin doğal ve kültürel çevreye saygılı davranışlarını öngören bir hedef bölge gelişim planı, turizmden beklenen yararları sağlamak için önemli bir başlangıçtır (Stankey vd., 1985; McCool, 1996; WTO, 1997). Turizm, kendinden beklenen toplumsal yararları sağladığı zaman iki taraf arasında olumlu iletişim, saygı, uzlaşma, yardımseverlik, konukseverlik, barış ve hoşgörü gibi olumlu kültürel değerler sağlanacak (Pedersen, 2002), kültürel mesafeler azalacaktır (McKercher ve Chow, 2001). Arzu edilmeyen 
durumlarda, önyargı, tek tipleştirme, yabancı düşmanlığı, ayrımcılık ve ırkçılık, eğitim ve bilinç eksikliği ya da beklenen zarar sonucu iki taraf arasında olumsuz iletişim, çatışma, ilgisizlik ya da saldırganlık yaşanabilir (Doğan, 2004; Yılmaz, 2007).

\section{FESTIVALLER VE YEREL HALK}

Festivaller halkın katılımına açı olan, (genelde kültürel özellik gösteren) belirli bir konunun kutlanması amacıyla, belirli bir yerde, genelde kısa vadeli gerçekleştirilen ve yinelenen etkinliklerdir (Picard ve Robinson, 2006). İnsan uygarlığının gelişimi boyunca festivaller, önemli her türden olayın kutlanması, toplumsallaşma, rahatlama, yenilenme, dayanışma gibi önemli toplumsal işlevleri gerçekleştiren, çok önemli toplumsal araçlar olmuştur.

Güncel festivaller turizm, bölge imajı ve marka gelişimi ve doğal olarak rekabet gücü, istihdam ve ekonomik gelişim için yaşamsal öneme sahiptir. Festivaller, bölgenin doğal ve kültürel sermayesinin sunumu, önemli tarihsel ya da simgesel olayların yeniden canlandırılması (sahnelenmesi), farklılıkların kutlanması yoluyla aidiyet ve toplumsal dayanışmanın desteklenmesi gibi işlevler de sağlarlar (Mair, 2018). Konularına göre yerel kültür, yerel mutfak, kırsal yaşam ve tarım, ulusal ya da bölgesel kimlik, yerel üretim ve el sanatları; ya da müzik, tiyatro, sinema gibi gösteri sanatları; ayrıca önemli tarihsel ve dinsel olayların kutlanması amacıyla düzenlenen festivaller, etkinlik turizminin önemli araçlarından biri olarak sayılmaktadır.

Festivaller, genelde kültür ile içsel biçimde bağlantılıdır; yüksek kültür ve sanat, yerel gelenekler ve miras, popüler ya da etnik kültür ile ilgili düzenlenebilirler (Helgadóttir, 2018). Bu anlamda, yerel halkın yaşam biçiminin kutlanması amacını taşıyabilir, kültürel çekim unsurunu güçlendirebilirler. Burada yerel kültürün özünü ve anlamını yitirip yozlaşmadan sahnelenmesi önem taşıyacaktır (Cohen, 1979). Ayrıca, festivale katılan yerel halk, rol değiştirerek ziyaretçi konumuna geçecek, bu yolla rekreasyonel yarar sağlayarak yaşam kalitesini yükseltme olanağına kavuşacaktır (Sayarı ve Gün, 2018).

Festivaller, özellikle kısa süreli ve yinelenen etkinlikler oldukları için, bölgede geçici ziyaretçi yoğunluğu ve kalabalığa neden olarak yerel halkın gündelik yaşamını etkilerler. Ancak yoğunluğun olmadığı yer ve zamanlarda düzenlenerek, turistik yoğunlaşmanın aşılması için bir turistik ürün çeşitlendirmesi aracı olarak da kullanılabilirler (Olalı ve Timur, 1988).

Festivallerin olumlu sosyal etkileri arasında, toplum gururunun artışı, sosyal ve fiziksel altyapıda iyileşme, yerel geleneklerin korunması, yerel halkta olumlu imaj ve öz algı gelişimi sayılabilir. Ayrıca toplumsal kaynaklar ve bunların kullanımına yönelik farkındalık artışı, daha etkin işbirliği ağlarının gelişimi, istikrar, kapsayıcılık, güven ve dayanışma yoluyla sosyokültürel sermayenin gelişimi de festivallerin toplumsal yararları arasındadır. Bu yolla, toplumun bireyleri ya da ziyaretçi - yerel halk arasında kurulması aksi halde mümkün olmayacak bir iletişim ve birliktelik kurulabilir. Bu sermayenin harekete geçirilmesi ve başarılı sunumu, festivallerin uzun vadeli başarısında önemli rol oynayacak ve dolaylı olarak yerel halkın da festivalleri desteklemesini sağlayacaktır. Olumsuz etkiler arasında da gündelik yaşamı sekteye uğratacak yoğunluk, kirlilik ve özellikle gürültü ve görüntü kirliliği, vandalizm, kültürün ve toplumsal ilişkilerin ticarileşmesi, toplum içi çatışmalar sayılmaktadır (Wilmersdörffer ve Schlicher, 2018).

Festivallerin toplumsal etkisinin ölçülmesinde ise, yerel halkın bu etkileri algılama biçimlerinin değişkenliği, ayrıca değişime yönelik toplumsal tutum ve algıların ölçümü yoluyla etkilerin 
belirlenmesi zorunluluğu nedenleriyle, genel-geçer bir ölçüm aracı bulunmamaktadır. Bu nedenlerle, ölçüm için örnek olayda yer alan yerel halkın sınırlarının çizilmesi, diğer paydaşların ve festivalin özelliklerinin belirlenmesi ve durumsal bir ölçek geliştirilmesi gereklidir. Toplumsal algıların ölçümünde etkilerin parasal değerlere bağlanması bir diğer yaklaşımdır (Wilmersdörffer ve Schlicher, 2018).

Etkilerin ölçümüne yönelik geliştirilen bir modele göre, festivalin etkileri gerçekleştiği alana, hedef bölgenin imajına, yerel halkın toplumsal uyumuna ve kültürel kimliğine yönelik olabilmektedir. Buna göre, festivalin yerel halkın normal yaşamında neden olduğu değişimin yerel halk tarafından genel olarak olumlu ya da olumsuz algılanması, ana paydaş olarak yerel halkın festivale yönelik genel tutumunu yansıtmaktadır. Bu tutum da yerel halkın festivale ve ziyaretçilere yönelik toplu davranışlarını ve dolayısıyla festivalin başarısını ve sürdürülebilirliğini belirlemektedir. Bu etkilerin yerel yönetim ve işletmeler tarafından başarılı yönetimi de daha olumlu tutum ve davranışlara yol açabilir. Burada da kabul edilebilir değişim sınırlarının belirlenmesi ve etkilerin sınırlandırılması önemli bir başlangıç noktasıdır (Wilmersdörffer ve Schlicher, 2018).

Festivallerin sosyal etkilerinin ölçülmesi konusunda bir diğer yaklaşımda, Delamere vd., (2001) festivallerin sosyal etkilerini ölçmek için Festival Sosyal Etki Tutum Ölçeği'ni (Social Impact Attitude Scale - FSIAS) geliştirmişlerdir. Festivallerin olası sosyal etkilerini belirleyen ölçeğin geliştirilmesinde ilgili literatür dikkate alınarak bir liste oluşturulmuş ve faktör analizine tabi tutarak sosyal etkileri; "sosyal fayda" ve "sosyal maliyet" olarak iki şekilde tanımlamışlardır. Sosyal fayda faktörü "toplumsal fayda" ve "kültürel fayda" alt faktörlerinden oluşmakta ve toplum imajı1, tanınırlık, gurur duyma, kimlik oluşturma, kültür etkileşimi, ekonomi ve refah düzeyi ile ilişkilendirilmektedir. Sosyal maliyetler için de alt faktörler "yaşam kalitesi" ve "toplumsal kaynak kaygısı" faktörleri çıkmıştır ve kalabalık, trafik, gürültü, çöpler ve kamu kaynakların dağılımı, vergi dağılımı, paydaşlar arasındaki adalet gibi konularla ilişkilendirilmiştir.

Delamere (2001) çalışmasını genişleterek tekrarladığında ise sosyal faydalar faktörünü oluşturan "toplumsal fayda" ve "bireysel fayda" alt faktörlerini elde ederken sosyal maliyet faktörünün alt faktörü çıkmamış sadece yaşam kalitesi faktörünün (kalabalık, trafik, gürültü, çöpler gibi) bileşenleri ile tanımlanmıştır.

Fredline vd., (2003) festivallerin sosyal etkilerini ölçmek için geliştirdikleri ölçeklerinde ise altı faktör elde etmişlerdir. Bunlar; sosyal ve ekonomik kalkınma faydaları, adalet ve rahatsızlık ile ilgili endişeler, kamu tesisleri üzerindeki etkileri, davranış ve çevre üzerindeki etkileri, toplum üzerindeki uzun vadeli etkileri ve bazı mal ve hizmetlerin fiyatları üzerindeki etkileri şeklindedir.

Small (2007) ise festivallerin sosyal etkilerini ölçmek yeni bir ölçek çalışması gerçekleştirdiği çalışmasında altı faktör elde etmiştir. Bu faktörler: rahatsızlık (trafik, park, gürültü gibi), toplumsal kimlik ve uyum faktörü (toplumsal kimlik, gurur oluşturma, festivale katılım vb.), kişisel hayal kırıklığı (ziyaretçilerden rahatsız olma, yerel halkın festivalden kaçması, günlük rutinlerin bozulması vb.), eğlence ve sosyalleşme fırsatları (yeni insanlarla tanışma, sosyal iletişim fırsatları, kültürel paylaşım vb.), toplumsal büyüme ve gelişme (yeni iş fırsatları, istihdam yaratılması, toplum içinde yeni yeteneklerin gelişmesi vb.) ve davranış sorunlarıdır (vandalizm, suç odaklı davranışlar, eşit olmayanların davranış sorunları vb.).

Yolal vd., (2016) festivallerin etkilerini inceledikleri makalelerinde, yerel halkın refahı (well-being) üzerinde durmuşlardır. Festivallerin sosyo-kültürel etkileri ve bu etkiler ile festivale katılan yerel halkın refahı arasındaki ilişkilerini inceledikleri çalışmalarını Adana Altın Koza Film Festivali'nde 
gerçekleştirmişlerdir. Sosyal etkileri; toplumsal fayda, kültürel fayda, yaşam kalitesi ve toplumsal kaynak olarak boyutlandırarak festivale katılan 500 kişi ile anket çalışmalarını gerçekleştirmişlerdir. Bu araştırmada, yerel festivallerin sağladığı bölge imajı, tanıtımı ve gelişimi gibi toplumsal faydaların ve eğitim olanakları, kültürel gelişim gibi toplumunun ilerlemesinde etkili gördükleri kültürel etkilerin yerel halkın refahı üzerinde olumlu sonuçlar doğurduğunu tespit etmişlerdir. Fakat yerel halkın yaşam kalitesini belirleyen yoğunluk, trafik sıkışıklığı, trafik gürültüsü ve vandalizm gibi etkilere bakıldığında festivallerin yerel halkın refahını olumsuz etkilediği ve yaşam kalitelerini bozduğunu yönde sonuçlar elde etmişlerdir.

Sert (2017), festivallerin yerel halk üzerindeki sosyal etkilerini her yıl gerçekleştirilen "Uluslararası Beypazarı ve Yöresi Festivali" örneğinde incelemiştir. 320 anket ile gerçekleştirdiği araştırmasında yerel halkın en çok üzerinde durduğu konunun festivallerin toplumsal etkileri olduğu görülmüştür ve katılımcıların büyük çoğunluğu festivalin olumlu toplumsal yararlar sağladığı görüşünde birleşmiştir. Bölge imajını olumlu yönde etkilemesi, ilçenin tanınırlığını arttırması, toplumsal kimliği güçlendirmesi, farklı kültürlerle karşılaşma olanağı sunması, eğlenme fırsatı yaratması, ilçe halkının refahına katkıda bulunması, yerel halkın kültür yaşamına olumlu katkıda bulunması, yaşam kalitesini yükseltmesi, yeni bilgi ve beceriler kazandırması gibi toplumsal etkilerde festivaller yerel halk tarafından desteklenmektedir. Araştırmada, taşıt trafiğinin artması, yörenin kalabalıklaşması gibi ifadelerde ise orta düzeyde katılım olduğu görülse de yöre halkının günlük yaşamını bozduğuna ve yaşantısına bir saldırı olduğuna dair ifadelere katılım görülmemiştir.

Pavlukovic vd. (2017), festivallerin yerel halk üzerindeki sosyal etkilerini belirlemek ve boyutlarını tespit etmek amacıyla Sırbistan ve Macaristan'da düzenlenen iki büyük müzik festivalinde araştırmalarını gerçekleştirmişlerdir. Festivallerin olumlu sosyal etkileri olarak; festival süresince yerel halkın yüksek güvenlik seviyesi algılaması, yerel halkın festivale ev sahipliği yaparken gurur duyması ve tanıtımının yapıldığını düşünmesi ve yerel halkın festival süresince gelir arttırıcı çeşitli fırsatlar yakalaması gibi görüşlerin ağırlıklı olduğu görülmüştür. Diğer taraftan olumsuz etkilere bakıldığında festival süresince suç oranlarının artması, kabul edilemez seviyelerde çöplerin oluşması, gürültü seviyesine duyulan rahatsızlık, kalabalık ve bu yabancı kalabalığın yerel halkın günlük rutinini bozması ile özel alanlarına girmesi gibi etkiler ön plana çıkmıştır.

Chi vd. (2018), 2014 yılında Brezilya'da düzenlenen FIFA Dünya Kupası sırasında ev sahibi yerel halk ile yaptıkları anket çalışmasında, mega etkinliklerin yerel halk üzerindeki etkileri ve yerel halkın etkinliklere olan desteğini araştırmışlardır. Brezilya'da beş ev sahibi şehirde etkinlik öncesi ve sonrasında gerçekleştirdikleri araştırmada, etkinliklerin olumlu etkileri, olumsuz etkileri, hükümetlere güvenme ve etkinlikleri destekleme sorularına yer verilmiştir. Araştırma sonuçları, yerel halkın mega etkinliklerin etkilerini olumlu algıladığı düzeyde, etkinliklere olan desteğini olumlu yönde etkilediğini, olumsuz etkilerine ilişkin algılarının ise etkinliklere olan desteklerini olumsuz yönde etkilediğini göstermiştir. Yerel halk tarafından algılanan olumlu etkiler (faydalar) olumsuzlukları (maliyetleri) aşarsa, etkinlikleri desteklemeye ve kaynak oluşturmaya istekli olmaktadırlar. Ayrıca çalı̧̧mada yerel halkın mega etkinliklere olan bağlılık düzeyleri, olumlu etkilerini daha fazla görmelerini ve daha fazla destek vermelerini etkilediğini de göstermektedir. Yerel halk festivallerin olumlu etkilerinden; festivallerin toplumları yakınlaştırdığı, yörenin imajını geliştirdiği, bölgenin tanıtımını desteklediği ve çevresel farkındalığı arttırdığı görüşlerine önemi ölçüde katılmıştır. Festival sırasında çöp ve dağınıklık oluşması, doğal çevreye zarar verilmesi, gürültü ve görsel kirlilik oluşması ve suç oranlarında artış yaşanması gibi olumsuz etkilerine düşük düzeyde katılmışlardır. 
Wilmersdörffer ve Schlicher (2018), Wacken'da her yıl düzenli olarak gerçekleşen "W:O:A" (Wacken Open Air) müzik festivalinde zamanla artan ziyaretçi akımını ve zaman içerisinde yerel halk üzerinde neden olduğu etkileri incelemişlerdir. İlki 1990 yılında gerçekleşen festivalin ilk beş yılı boyunca toplam ziyaretçi sayısının 5000'i geçmemesi, yerel halk tarafından herhangi bir şikâyete veya herhangi bir önlem alma durumunu gerektirecek olumsuz bir duruma neden olmamıştır. Fakat yine de beş yılın sonunda yavaş yavaş toplumsal etkilerin başladığı görülmeye başlanmıştır. Dikkate değer etkiler, festivalin zamanla duyulması ile 1996 yılında, özellikle bölgesel alt yapı taşıma kapasitesinin çok üstünde (10.000) ziyaretçinin gelmesiyle görülmüştür. Bu dönemde yerel halkın, trafik sıkışıklığı, gürültü, marketlerdeki sıra uzunlukları, çöpler ve vandalizmden oldukça şikâyetçi olduğu tespit edilmiştir. 1998 yılında 18.000 ziyaretçinin gelmesi ise yerel halkı ve yerel otoriteleri ayağa kaldırmış, konunun tartışılması için festival komitesi ile görüşmelere başlanmıştır. Festivali iptal etmek isteyen yerel halka karşı festival komitesi proaktif önlemlerin alınacağı ve bu olumsuz etkilerin önüne geçilebileceğini savunarak festivalin devamını sağlamıştır. 2000 yılında gerçekleşen festivalde önceden alınan birtakım önlemler ile yerel halkın olumsuz etkileri dile getirmesinde azalmalar olduğu gözlenmiştir. Özellikle yerel halkın da festivale katılımının sağlanması ile yerel halkın festivale karşı davranışlarında; ziyaretçiler ile beraber vakit geçirme ve arkadaşlık kurma gibi olumlu değişimler ve bölgelerinin tanıtımı için çeşitli çalışmalarda bulunarak gurur duyma gibi olumlu duyguların geliştiği gözlenmiştir. Yazarlar sonuç olarak çalışmalarında, festivallerin yerel halk üzerinde olumlu ve olumsuz birtakım etkilerin olduğunu, fakat birtakım önlemler ile bu olumsuz etkilerin azaltılabileceği gibi yerel halk ve ziyaretçilerin memnuniyet düzeylerinde artışın yaşanabileceğini sonucuna varmışlardır.

Mega etkinliklerin ev sahibi halk üzerindeki etkilerini ve etkinliğe karşı tutumlarını etkileyen faktörleri inceleyen Atçı vd. (2016), araştırmalarını Mersin'de gerçekleşen 17. Akdeniz Oyunları'nda gerçekleştirmişlerdir. Ekonomik faydalar, sosyal faydalar, ekonomik maliyetler, sosyal maliyetler ve imaj geliştirme üzerinde durdukları çalışmalarında yöre halkının cevaplarına göre, imaj geliştirme ve ekonomik faydaların önemli düzeyde olduğu görülmüştür. Yerel halk gerçekleşen etkinliğin yörenin imajını geliştirdiğini ve önemli ekonomik katkılar sunduğunu düşünmektedir. Yeni yatıımların yapılması, istihdam fırsatlarının yaratılması ve etkinlikle ilgili yeni tesislerin yapılması yörenin ekonomik kalkınmasına katkı sağladığını düşündürmektedir. Yerel halk üzerindeki ekonomik ve sosyal maliyetler açısından bakıldığında ise yerel halkın etkinlikler sırasında yaşanacak olumsuzluklar söz konusu olduğunda desteğin azalacağı ama genel olarak faydaların maliyetlerden fazla olduğu düşüncesi ile bu tür etkinlikleri destekledikleri yönündedir.

Son olarak, Deery ve Jago (2010), Avustralya Açı Tenis Turnuvası ve Schoolies Week etkinliklerinde yaptıkları çalışmada, katılımcıların anti sosyal davranışlarını çok ciddi bir sosyal maliyet olarak belirlemişlerdir. Özellikle sarhoş, gürültücü ve şiddet içerikli davranışlar, basında da yoğun ilgi gördüğü için yerel toplumun güvenlik duygusunu zedelemekte, etkinliklerin bütün sosyal faydaları ve neden oldukları topluluk gururuna rağmen, yerel halkın etkinliklere ilgisinin azalmasına neden olmaktadır.

\section{YÖNTEM}

Bu çalışma, festivallerin yerel halk üzerindeki sosyal etkileri keşfetmeyi amaçlamaktadır. Bu amaçla araştırma tasarımı olarak nitel araştırma yöntemi içerisinde yer alan; araştırma konusu ve sorusu ile ilgili fikir ve bilgi edinmeye, anlayış kazanmaya yarayan keşifsel araştırma tasarımı kullanılmıştır (Brown ve Tracy, 2012). 
Festivallerin yerel halk üzerindeki etkilerinin keşfedilmesi amacıyla verilerin elde edilmesi, İzmir'in Urla ilçesinde sürekli ikamet eden yerel halk ile derinlemesine görüşme tekniği ile gerçekleştirilmiştir. Araştırma evreni Urla ilçe merkezinde ikamet eden ve Urla ilçesinde düzenlenen çeşitli festivallerden etkilenildiği düşünülen ve tesadüfi örneklem yöntemiyle seçilen tüzel ve gerçek kişilerden oluşmaktadır. Araştırmanın Urla'da gerçekleştirilmesinin nedeni, Urla'da sadece tek bir döneme sıkıştırılan bir festivalden ziyade, yıl içerisinde farklı dönemlerde çeşitli festivallerin gerçekleşmesidir. Urla'da yaşayan yerel halkın yıl içerisinde birden fazla festivalle iç içe olması ve çeşitli etkilerin daha uzun süre zarfında, daha derinlemesine gözlemleme şansına sahip olduğu düşüncesidir. Araştırma süre ve maddi kısıtlardan dolayı Urla ilçesi ile sınırlandırılmış ve 2019 yılı Nisan - Haziran ayları sürecince gerçekleştirilmiştir.

Örneklemi nitel araştırma yöntemine uygun olarak, araştırma sorusunun yanıtı olabilecek kavramların tekrar etmeye başladığı aşamaya kadar (Yıldırım ve Şimşek, 2005) kolayda örneklem ile seçilen Urla ilçesinde, daha çok festival bölgelerine yakın ve merkez lokasyonda ikamet eden yerel halk ve yerel işletme sahipleri oluşturmaktadır. Literatüre bağlı kalarak geliştirilen sorular keşifsel bilgi edinmeyi amaçlayarak, görüşmelerin akışına göre şekillendirilmiştir. Toplamda 32 kişi ile yaklaşık 30 ile 60 dakikalık süre aralığında yarı yapılandırılmış soru formatı ile görüşmeler gerçekleştirilmiştir. Elde edilen verilerin yazıya dökülmesi ve araştırmacıların elde edilen verileri ilgili literatür temelinde İçerik analizine tabi tutulmasıyla bulgular elde edilmiştir. İçerik analizi yapılırken, elde edilen verilerin kodlanmasında ve gruplaştırılmasında birçok çalışmada kabul gören ve kullanılan Delamere vd., (2001) ve Delamere' in (2001) Festival Sosyal Etkiler Tutum Ölçeği dikkate alınmıştır.

\section{ÖRNEK OLAY: URLA İLÇESİ VE FESTIVALLERI}

İzmir İlinin merkezine 38 kilometre uzaklıkta olan ve kendi adını taşıyan yarımadanın merkezinde yer alan Urla, İzmir' in batısında yer alan ilçelerinden biridir. Doğusunda Güzelbahçe ve Seferihisar; batısında Çeşme kuzeybatısında Karaburun; kuzeyinde ve güneyinde Ege Denizi ile sınırlanmıştır. Yüzölçümü 728 km²'dir. Otuz yedi mahallesi vardır ve 2018 verilerine göre 66.360 nüfusa sahiptir. Deniz seviyesinden 65 metre yükseklikteki ilçede hâkim bitki örtüsü; delice, zeytin, koca yemiş, defne, mersin ve makilerdir. Urla ilçesi, kıyıdan merkez Urla ile birlikte İskele, Denizli, Çeşmealtı, Menteş, Demircili gibi yerleşimleri de kapsamaktadır.

Antik çağdan bu yana bölgeye Klazomenai ve Vourla denmektedir. Kıyı kesiminin genel adı, 1970'lere kadar "Kilizman" diye dilimizde yaşayan "Klazomenai"dir; iç bölgelerin adı ise "Vourla" diye anılmaktadır. Tarihi antik çağlara dayanan ilçe günümüzde önemli hedef bölgeler arasında yer almaktadır. M.Ö. 6000'li yıllara kadar uzanan tarihçesi ve yeşil tepeleri, yeşil düzlükleri ve bağları, koyları ve Akdeniz ikliminin bütün özelliklerine sahip olması ile Urla, yurtiçi ve dışından talep görmektedir.

İlçede her yıl çeşitli etkinlikler ve festivaller düzenlenmektedir. Mart Dokuzu Urla Ot Festivali, Urla Bağ Bozumu Şenliği, Urla Sanat Günleri ve Uluslararası Urla Enginar Festivali en önemli ve en çok ses getiren etkinlikler arasındadır (T.C. Urla Kaymakamlığı, 2019; T.C. İzmir Valiliği, 2019; Urla Belediyesi, 2019). Tablo 1 'de Urla ilçesinde 2019 yılı içerisinde gerçekleşen etkinliklere yer verilmiştir. 
Tablo 1. 2019 Yılı Urla' da Gerçekleşen Etkinlikler

\begin{tabular}{|c|c|c|}
\hline Etkinlik Dönemi & Etkinlik Adı & Etkinlik Yeri \\
\hline 10-13 Ocak 2019 & $\begin{array}{l}\text { Necati Cumalı Edebiyat Ödülleri } \\
\text { Yarışması ve Necati Cumalı Buluşması }\end{array}$ & $\begin{array}{l}\text { Necati Cumalı Anı ve Kültür Evi, Urla } \\
\text { Atatürk Kültür Merkezi }\end{array}$ \\
\hline 23-24 Mart 2019 & Urla Ot Festivali & Urla Merkez ve köyler \\
\hline 26-28 Nisan & Uluslararası Enginar Festivali & $\begin{array}{l}\text { Urla Cumhuriyet Meydanı Eski } \\
\text { Tamirhane Binası, Malgaca Pazarı, } \\
\text { Sanat Sokağı, Urla Atatürk Kültür } \\
\text { Merkezi }\end{array}$ \\
\hline $\begin{array}{l}26 \text { Nisan - } \\
06 \text { May1s } 2019\end{array}$ & $\begin{array}{llll}\text { Zeytinli } & \text { Köşk } & \text { Uluslararası Sanat } \\
\text { Festivali } & & & \\
\end{array}$ & Urla Merkez \\
\hline 24 Mayıs & Arnavut Böreği Festivali & Urla Cumhuriyet Meydanı \\
\hline 4-5 Haziran & Tanju Okan Yat Yarışları & Urla iskele liman içi \\
\hline 12 Haziran & Uçurtma Festivali & Kuşçular Köyü Şifa Tepesi \\
\hline 13-14 Haziran- & Samutbaba Festivali & Samutbaba Türbesi \\
\hline $\begin{array}{ll}18-21 & \text { Temmuz } \\
2019 & \end{array}$ & $\begin{array}{l}\text { 9. Uluslararası Urla Toprak Sahne } \\
\text { Tiyatro Festivali }\end{array}$ & Urla Merkez \\
\hline Ağustos & Köy Tiyatroları Şenliği & $\begin{array}{l}\text { Yaylacılar Köyü, Balıklıova köyü, } \\
\text { Barbaros Köyü, Badem köyü }\end{array}$ \\
\hline 14-16 Ağustos & 26. Geleneksel Bağbozumu Festivali & $\begin{array}{l}\text { Urla Cumhuriyet } \\
\text { Meydanı, Sanat Sokağı, Malgaca } \\
\text { Pazarı, Eski Tamirhane Binası }\end{array}$ \\
\hline 03-05 Eylül & Nohutlanan Köyü Kavun Şenliği & Nohutlanan Köyü \\
\hline 06-08 Eylül & Barbaros Oyuk Festivali & Urla Cumhuriyet Bulvarı \\
\hline
\end{tabular}

Kaynak: İzmir Büyük Şehir Belediyesi, Kültür Sanat (2019)

\section{BULGULAR}

Çalışmanın amacı doğrultusunda Urla ilçesinde gerçekleştirilen araştırma 2019 yılı Nisan ve Haziran ayları sürecince gerçekleştirilmiştir. Yıl boyunca süren festivaller göz önüne alındığında bu dönem içerisinde çalışmanın yapılmasının nedeni; önemli festivallerin gerçekleştirilmiş olması ve etkilerini belirlemek için uygun bir zaman dilimi olarak görülmesidir. Araştırmada için 32 katılımcı ile görüşülmüştür. Araştırmaya katılan 32 katılımcının demografik özellikleri Tablo 2' de verilmektedir.

Görüşmelerden elde edilen verilerin yazıya dökülmesinden sonra Festivallerin Sosyal Etkileri kapsamında gerçekleştirilen içerik analizi Tablo 3'de ve EK 1'de verilmektedir. Yapılan analizde 17 ayrı ifade kodlanmıştır ve toplamda 567 frekansla bu ifadelerden bahsedildiği görülmektedir. Yapılan kodlamalar daha sonra Sosyal Fayda ve Sosyal Maliyet faktörleri altına Tablo 4'de yerleştirilmiştir. 
Tablo 2. Katılımcıların Demografik Özellikleri

\begin{tabular}{|c|c|c|c|c|c|}
\hline Cinsiyet & $\mathbf{n}$ & $\%$ & Meslek & $\mathbf{n}$ & $\%$ \\
\hline Kadın & 20 & 62,5 & Belediye Çalışanı & 2 & 6,25 \\
\hline Erkek & 12 & 37,5 & Memur & 6 & 18,75 \\
\hline Toplam & 32 & 100 & Esnaf & 15 & 46,87 \\
\hline & & & $\begin{array}{ll}\text { Özel } & \text { Sektör } \\
\text { Çalışanı } & \\
\end{array}$ & 3 & 9,37 \\
\hline Yaş & $\mathbf{n}$ & $\%$ & Çiftçi & 2 & 6,25 \\
\hline$<=30$ & 2 & 6,25 & Ev Hanımı & 1 & 3,12 \\
\hline $31-40$ & 5 & 15,63 & Emekli & 3 & 9,37 \\
\hline $41-50$ & 18 & 56,25 & Toplam & 32 & 100 \\
\hline$>=50$ & 7 & 21,87 & & & \\
\hline Toplam & 32 & 100 & & & \\
\hline
\end{tabular}

Tablo 3. Festivallerin Sosyal Etkilerine İlişkin İçerik Analizi Bulguları

\begin{tabular}{|c|c|c|c|c|c|c|c|}
\hline \multirow{2}{*}{$\begin{array}{l}\text { No } \\
1 .\end{array}$} & Kodlar & Frek. & $\%$ & No & Kodlar & Frek. & $\%$ \\
\hline & İlçe tanınırlığı & 64 & 11,28 & 10. & İlçe halkının ekonomiye katılması & 26 & 4,58 \\
\hline 2. & Trafik sıkışıklığı & 56 & 9,87 & 11. & Ulaşım & 23 & 4,05 \\
\hline 3. & Çöpler & 51 & 8,99 & 12. & $\begin{array}{l}\text { İlçe halkının ilçesini geliştirmesinde } \\
\text { motive olması }\end{array}$ & 22 & 3,88 \\
\hline 4. & Kalabalık & 49 & 8,64 & 13. & Kültürlerle kaynaşma & 19 & 3,35 \\
\hline 5. & Gürültü & 49 & 8,64 & 14. & Yeni İnsanlar tanıma & 18 & 3,17 \\
\hline 6. & $\begin{array}{l}\text { İlçede yaşanan ekonomik } \\
\text { canlılık }\end{array}$ & 47 & 8,28 & 15. & $\begin{array}{l}\text { İlçe halkının düzenlemeye katılımı, yeni } \\
\text { beceriler edinme }\end{array}$ & 17 & 2,99 \\
\hline 7. & İlçe imaj1 & 37 & 6,52 & 16. & İlçe halkının ilçeye bağlılığının artması & 17 & 2,99 \\
\hline 8. & $\begin{array}{l}\text { İlçede yaşanan hareketlilik, } \\
\text { canlılık }\end{array}$ & 30 & 5,29 & 17. & Suç oranı & 15 & 2,64 \\
\hline 9. & Karmaşa & 27 & 4,76 & & & & \\
\hline & & & & & Toplam & 567 & 100 \\
\hline
\end{tabular}

Tablo 4'de, festivallerin sosyal faydalarının (toplumsal fayda ve kültürel/bireysel fayda) yerel halk tarafından (297 frekans, \%52,5) en fazla dikkate alınan konu olduğu görülmektedir. Özellikle yapılan görüşmelerin tamamında katılımcılar "toplumsal fayda" alt faktörü altında yer alan "ilçenin tanınırlı̆̆ından" bahsetmiş ve tüm ifadeler arasında 64 frekansla en fazla tekrarlanan ifade olmuştur. İlçede yaşanan ekonomik canlılık, ilçenin imajı, ilçe halkının ekonomiye katılması, motive olması gibi toplumsal fayda ve yeni kültürlerle, insanlarla tanışma, yerel halkın yeni beceriler edinmesi gibi kültürel/bireysel faydalar yerel halkın festivallere olan bakış açısını göstermektedir. Etkinlikler kapsamında yerel halkında etkinliklere katılması ve eğlenmesi kendileri için önemli olduğunu, ilçelerinden gurur duyduklarını ifade etmişlerdir. Bu kodlamalara ait örnek katılımcı ifadesine aşağıda yer verilmiştir. 
Tablo 4. Festivallerin Sosyal Etkilerine İlişkin Sosyal Etki Tutum Ölçeği'ne göre Bulgular

\begin{tabular}{|c|c|c|c|c|c|c|c|}
\hline \multicolumn{4}{|c|}{ Sosyal Fayda } & \multicolumn{4}{|c|}{ Sosyal Maliyet } \\
\hline Toplumsal Fayda & Frek. & $\begin{array}{l}\text { Kültürel Fayda } \\
\text { /Bireysel Fayda }\end{array}$ & Frek. & $\begin{array}{l}\text { Yaşam } \\
\text { Kalitesi }\end{array}$ & Frek. & $\begin{array}{c}\text { Toplumsal } \\
\text { Kaynak } \\
\text { Kayg1sı }\end{array}$ & Frek. \\
\hline İlçe tanınırlığ1 & 64 & $\begin{array}{l}\text { Kültürlerle } \\
\text { kaynaşma }\end{array}$ & 19 & $\begin{array}{l}\text { Trafik } \\
\text { sıkışıklığ1 }\end{array}$ & 56 & & \\
\hline $\begin{array}{l}\text { İlçede yaşanan } \\
\text { ekonomik canlılık }\end{array}$ & 47 & $\begin{array}{ll}\text { Yeni } & \text { İnsanlar } \\
\text { tanima } & \\
\end{array}$ & 18 & Çöpler & 51 & & \\
\hline İlçe imajı & 37 & $\begin{array}{l}\text { İlçe halkının } \\
\text { düzenlemeye } \\
\text { katılımı, yeni } \\
\text { beceriler edinme }\end{array}$ & 17 & Kalabalık & 49 & & \\
\hline $\begin{array}{l}\text { İlçede yaşanan } \\
\text { hareketlilik, canlılık }\end{array}$ & 30 & & & Gürültü & 49 & & \\
\hline $\begin{array}{l}\text { İlçe halkının } \\
\text { ekonomiye } \\
\text { katılması }\end{array}$ & 26 & & & Karmaşa & 27 & & \\
\hline $\begin{array}{l}\text { İlçe halkının ilçesini } \\
\text { geliştirmesinde } \\
\text { motive olması }\end{array}$ & 22 & & & $\begin{array}{l}\text { Ulaşım } \\
\text { Sikıntısı }\end{array}$ & 23 & & \\
\hline $\begin{array}{l}\text { İlçe halkının ilçeye } \\
\text { bağlılığının artması }\end{array}$ & 17 & & & Suç oranı & 15 & & \\
\hline Toplam & 243 & & 54 & & 270 & & \\
\hline Oran & $\% 43$ & & $\% 9,5$ & & $\% 47,5$ & & \\
\hline
\end{tabular}

\section{Katılımer 1:}

İlçemizde sürekli bir etkinlik gerçekleştiriliyor. Belediyemiz, halkımız buna destek veriyor. Bizler çok memnunuz. İlçemiz tanınıyor. Hareketleniyor. Bizlerde katılıyoruz. Satış yapıyoruz. Burada birçok kadın kendi el emekleri bir şeyler satıyor. Para kazanıyor. Festivallerde müzikler oluyor, eğlenceler düzenleniyor. Bizlerde eğlencelere katıllyoruz. İlçemiz hareketleniyor. Canlanıyor. Bazen çok kalabalık oluyor, gürültü oluyor. Ama o zamanda oradan uzaklaşıp sakin yerlere gidebiliyoruz. Festivaller belirli alanlarda yapıldığı için eğlenmek isteyen, satış yapmak isteyen oraya katılabilir. Sakinlik isteyen ise başka yerleri tercih edebilir.

Yapılan görüşmelerde katılımcıların kültürel / bireysel fayda olarak ele alınan sosyal fayda faktöründen bahsettiği görülmüştür. Katılımcılar festivaller süresince farklı insanlarla bir araya geldikleri, yeni insanlar tanıdıkları, kültürlerini tanıdıkları ve kültürlerini tanıttıkları arkadaşlıklar kurdukları yönünde ifadelerde bulunmuşlardır. Bu kodlamalara ait örnek katılımcı ifadelerine aşağıda yer verilmiştir.

\section{Katılimer 4:}

Enginar Festivali uluslararası bir festival. Yurtdışından gelenler vardı. İstanbul ve Ankara'dan birçok ziyaretçi geldi. Kalabalı oluyor ama biz kalabalıktan memnunuz. Bütün esnaf faydalanıyor, ekonomi canlanıyor. Herkes evde bir şeyler yapıyor. Ev yemekleri yapılıyor. Gelen 
misafirlerimize sunuyoruz. Kendi özel yemeklerimizi, el işlerimizi. Kültürümüzü canlandırıyoruz, tanıtıyoruz. Festivallere katılmak ve faydalanmak için artık birçok kişi becerisini de arttırdı. Hanımlar el işlerini geliştirdi, hediyelik eşyalar hazırlıyorlar.

Katilima 12:

Bu Enginar Festivali'nde yaklaşık 15 bin tane enginardan yemek yapıp satış yaptım. Her yıl gelenler artıyor. Gelen misafirler bizden tarif istiyor, biz de veriyoruz. Yemek kültürümüzü onlara anlatıyoruz, tarif veriyoruz, tadım yaptırıyoruz. Onlar da bizlere kendi yemek tarzlarından, kültürlerinden bir şeyler anlatıyorlar. Misafirlerimizle arkadaş oluyoruz. Bir sonraki sene yine geliyorlar. Urla her yıl daha da tanınır hale geldi. Sadece Enginar festivali değil, Urla'da çeşitli festivaller oluyor. Kimi müzik, kimi film. Her alanda ilgi duyanlar ilçemizde mutlu oluyor. Bizler de artık festival zamanları ne yapmamı gerektiğini, gerekli hazırlıkları biliyoruz.

Alt faktörler açısından Tablo 4 değerlendirildiğinde ise 270 frekansla yaşam kalitesi alt faktörünün oldukça önemli olduğu görülmektedir. Katılımcıların tamamı trafik sıkışıklığı, çöpler, kalabalık ve gürültüden bahsetmiş̧ir. Karmaşa, ulaşım sıkıntısı ve suç oranları da festivallerin diğer yaşam kalitesine olan etkileri olarak görüşmelerde ifade edilmiştir. Festivallerin yerel halk üzerindeki sosyal etkilerini araştıran bu çalışma olumlu veya olumsuz algılamaların tespitinden ziyade bu etkilerin neler olduğu bulmak ve önemini ortaya koymayı amaçladığından olumlu veya olumsuz bir değerlendirme yapılmamıştır. Katılımcıların yaşam kalitesi üzerindeki etkileri kodlamalarına ait örnek katılımcı ifadesine aşağıda yer verilmiştir.

Katılimer 19:

Festival zamanlarn gerçekten çok kalabalık oluyor. Turlarla gelenler oluyor. Özel araçlarılala gelenler oluyor. Trafik sıkışıyor. Her yerde bir gürültü ve kalabalık, karmaşa oluyor. İlk zamanlarda urla halkı olarak bizler şikâyetçi olurduk. Fakat zamanla bizlerde işin içine girdikçe, birlerde bir parçası oldukça memnun olmaya başladık. Satış yapıyoruz. Eğleniyoruz. Bizlerde festival öncesinde hazırlıklara katılarak şikâyetçi oldŭ̆umuz yerleri düzenlemeye başladık.

Yapılan görüşmelerdeki ifadeler incelendiğinde, katılımcıların özellikle festivallerin yıl içine yayılması ve ilçenin bu durumdan daha farklı şekilde etkilendikleri tespit edilmiştir. Örneğin yaşam kalitesini belirleyen faktörlerden trafik sıkışıklığı, çöpler, kalabalık gibi etkilerin yıl boyunca düzenlenen etkinliklerde deneyimli, temkinli ve hazır olunmasından dolayı olumlu değerlendirmeler yaptıkları görülmüştür. Yılda sadece bir kere değil, yıl boyu bir gelir kaynağı olarak değerlendirildiği ve yıl boyunca yerel halkın eğlendiği, motive olduğu tespit edilmiştir. Bu bulguya ait katılımcı ifadelerine aşağıda yer verilmiştir.

Katılıma 6:

Festival süresince ilçemiz dışarıdan çok fazla ilgi görüyor. Normalde yaz aylarında artan nüfus bu dönemlerde daha da fazla artıyor. Günübirlik eğlenmek için insanlar geliyor. Tabi bu durum trafik sorunlarına neden olabiliyor. Fakat biz Urla yerlisi olarak bu duruma alışmış durumdayız. Bizim ilçemizde neredeyse her ay bir etkinlik düzenleniyor. Nasıl olacağını, neler yapmamız gerektiğini biliyoruz. Belediye çalışanlarımız da bu konuda bilgili. Sürekli düzenlenen etkinlikler bizlere çok şey öğretti. Otopark sorunlarımızı biliyoruz ve buna çözüm arıyoruz. Ki böyle kalabalık dönemlerde belediye otopark alanları oluşturuluyor. Örneğin eskiden kalabalıktan şikâyet ederken şimdi onların geride bıraktıkları olumsuzluklardan etkilenmemek için alınan önlemler bizleri rahatlatıyor. Çöpler zamanında toplanıyor. Çalışan çalışmayan hepimiz katkı 
sağlamaya çalışıyoruz. Etkinlikler artık bizim yaşamımızın ve ilçemizin bir parçası. Bizler de etkinliklerde eğlenmeye başladık.

Katılimer 24:

Festival zamanlarında gerçekten çok kalabalık oluyor. Her gelen çöpünü bırakıyor, bir karmaşa oluyor. Ben esnaf olarak bu tür etkinliklerden oldukça fayda sağlamama rağmen bazen trafik ve gürültü bizleri de bunaltabiliyor. Ama genel olarak baktığımda alıştı̆̆ımızı görüyorum. Hatta artık her ay bir etkinlik olması bizi de mutlu ediyor. Yıl içinde en az 7, 8 tane festival oluyor. Bizlerde nasıl olacă̆ını, neler yapabileceğimizi görüyoruz. Bazen kendi çöplerimizi toplarken gelen misafirlerin de çöplerini topluyoruz. Bundan da zevk alıyoruz, gurur duyuyoruz.

Katılımoı 30:

Urla'da sürekli bir etkinlik ve festival oluyor. Bizler çok eğleniyoruz. Bizler de katılıyoruz. Kimimiz para kazanıyor, kimimiz yeni insanlarla tanışıyor. Illçemizle, yönetimimizle gurur duyuyoruz. Halkımız bu etkinlere açık fikirlilikle yaklaşıyor. Biz böyle tanınmak istiyoruz.

Analizlerde Toplumsal Fayda, Kültürel Fayda/Bireysel Fayda ve Yaşam Kalitesi ile ilgili ifadelere rastlarken, Toplumsal Kaynak Endişesi faktörüne yönelik; kamu kaynakların dağılımı, vergi dağılımı ve paydaşlar arasındaki adalet gibi ifadelere rastlanmadığından bir kodlama yapılamamıştır. Bu durum Delamere'in (2001) ikinci etapta geliştirdiği ölçek çalışmasını destekler niteliktedir.

\section{SONUÇ VE ÖNERILER}

Festivallerin önemli bir turistik çekim unsuru olarak hedef bölgenin turizm değerini arttırdığı bilinmektedir. Özellikle son zamanlarda bir turistik ürün çeşitlendirmesi aracı olarak, gelişmekte olan bölgelerde veya yoğunluğun olmadığı yer ve zamanlarda düzenlendiği görülmektedir. Bunula birlikte yapılan birçok çalışmada ekonomik, sosyal, kültürel ve çevresel değerler yaratan festivallerin ev sahibi yerel halk tarafından kabul edilmesinin, festivallerin sürdürülebilirliği için oldukça önemli olduğu kabul edilmektedir (Sert, 2017; Chi vd., 2018; Wilmersdörffer ve Schlicher, 2018). Festivallerin yerel halkın günlük yaşamında neden olduğu değişimin yerel halk tarafından genel olarak olumlu ya da olumsuz algılanması, ana paydaş olarak yerel halkın festivale yönelik genel tutumunu yansıtacak, bu tutum da yerel halkın festivale ve ziyaretçilere yönelik davranışlarını ve dolayısıyla festivalin başarısını ve sürdürülebilirliğini belirleyecektir (Wilmersdörffer ve Schlicher, 2018). Olumsuzlukların azaltılması, olumlu etkilerin arttırılması ile turizmin getirilerinden daha fazla yararlanabilen toplumların oluşturulması sağlanacaktır.

Bu kapsamda çalışma, festivallerin yerel halk üzerindeki sosyal etkilerini keşfetmeyi amaçlamaktadır. Çalışma tek bir festivale odaklanmak yerine, yıl boyunca festivallerin sürdüğü hedef bölgenin ele alınmasıyla, yerel halkın sürekli gündelik yaşamı üzerindeki etkilere odaklanarak, aynı konuda gerçekleştirilen diğer çalışmalardan ayrılmaktadır. Derinlemesine inceleme fırsatı yaratan bu durum, literatürde var olan sosyal etkilere ek olarak yeni etkilerin keşfedilmesiyle, çalışmaya özgün bir değer katmaktadır ve elde edilen bulgular ile var olan literatürün gelişimine katkıda bulunmaktadır. Ayrıca bölgeye ve toplumsal kültüre dayalı farklılık gösterebilecek etkilere uyumlu sürdürülebilir gelişme politikaları önerilerinin geliştirilmesi çalışmanın önemini ortaya koymaktadır.

İzmir ilinin Urla ilçesinde gerçekleştirilen araştırmada elde edilen bulguların içerik analizi ve kodlamaları Sosyal Etki Tutum Ölçeğine (Delamere vd., 2001; Delamere, 2001) göre yapılmıştır ve 3 
faktörün altına yerleştirilmiştir. Festivallerin sosyal etkileri kapsamında yerel halkın görüşlerine göre, sosyal fayda faktörü altında toplumsal fayda ve kültürel/bireysel fayda, sosyal maliyet faktörü altına yaşam kalitesi alt faktörleri oluşmuştur.

Elde edilen verilere göre yerel halk, festivallerin ilçe tanınırlığını arttırdı̆̆ı, imajını geliştirdiği ve ilçede ekonomik canlılık yarattığını düşünmektedir. Özellikle ekonomiye katılarak kendileri içinde fayda sağladıkları ve bu konuda motive oldukları görülmüştür. Ayrıca yerel halkın festivallere katılım sağlamalarıyla birlikte ziyaretçiler ile beraber vakit geçirme ve arkadaşlık kurma gibi olumlu gelişmeler ve yörelerinin tanıtımı için çeşitli çalışmalarda bulunarak ilçeden ve kendinden gurur duyma gibi olumlu duyguların geliştiği, böylece bu etkiler göz önüne alındığında yerel halkın festivalleri desteklediği görülmüştür.

Ayrıca araştırma bulgularında, festival dönemlerinde yaşanan trafik sorunları, çöpler, kalabalık, gürültü ve karmaşa gibi yaşam kalitelerini belirleyen etkilerin varlığı tespit edilmiş ve olumsuz olarak algılanan bu sorunların önemi hakkında görüşler elde edilmiştir. Bu kapsamda araştırmanın diğer önemli bir sonucu; elde edilen olumsuz etkilerin en aza indirilmesi ve olumlu etkilerin desteklenmesi açısından, festivallerin gerçekleştiği bölgenin ve dönemin önemli olduğudur. Etkinliğin mevsimsellik özelliği (Kozak vd., 2008) ile tek bir dönem ve tek bir bölgede gerçekleştirilen festivallerde yaşanacak yoğunluğun neden olacağı olumsuz etkilerin azaltılması açısından, yıl içine yayılan festivallerin yapılması hem yerel halkın hem yerel yönetimlerin deneyim, alışkanlık ve alınacak önlemler açısından desteklendiği görülmüştür. Ayrıca yaşanan yoğunluktan kaçmak isteyen yerel halk için festivalin gerçekleştiği "ön bölgeler "in dışında, "arka bölgeler" in yaratılması (MacCannell, 1974), yoğunluktan etkilenmek istemeyen yerel halk için önemli olduğu söylenebilir. Diğer bir öneri olarak, festivallerin planlanmasında hedef bölgelerin taşıma kapasitesinin dikkate alınması (İ̧̧öz vd., 2009), olumsuz etkilerin önlenmesi açısından önemli olduğu düşünülmektedir.

Sonuç olarak bu çalışmada elde edilen bulgular, festivallerin planlanmasında olumlu etkileri teşvik edecek ya da olumsuz etkileri en aza indirecek stratejilerin planlanması ve uygulanması açısından önemli olmaktadır. Yeni bir festival geliştirmede yerel halkın destekleyecek şekilde sosyal faydalar elde etmesi ve festivalin sürdürülebilir olması açısından çalışmanın değerlendirilmesi önemli bir husustur. Ayrıca farklı bölgelerde gerçekleştirilecek olan festivallerin sosyal etkileri altında yatan boyutlardaki benzerlikleri veya farklılıkları tespit etmeye yönelik yeni çalışmalara alt yapı oluşturacağı da düşünülmektedir.

\section{KAYNAKÇA}

Atçı, D., Unur, K. and Gürsoy, D. (2016). The Impacts of Hosting Major Sporting Events: Resident's Perceptions of the Mediterranean Games 2013 in Mersin. International Review of Management and Marketing, 6(1): 139-145.

Brown, T. J. and Tracy, A. S. (2012). Exploratory, Descriptive, and Casual Research Designs, MR (1st ed.). South Western: Cengage Learning.

Chi, C. G., Ouyang, Z. and Xu, X. (2018). Changing Perceptions and Reasoning Process: Comparison of Residents' Pre- and Post-Event Attitudes. Annals of Tourism Research, 70: 39-53.

Cohen, E. (1979). A Phenomenology of tourist experiences. Sociology, 13(2): 179-201.

Deery, M. and Jago, L. (2010). Social impacts of events and the role of anti-social behaviour. International Journal of Event and Festival Management, 1(1): 8-28. 
Delamere, T. A. (2001). Development of a Scale to Measure Resident Attitudes toward the Social Impacts of Community Festivals, Part 2: Verification of the Scale. Event Management, 7(1): 25-38.

Delamere, T. A., Wankel, L. M. and Hinch, T. D. (2001). Development of a scale to measure resident attitudes toward the social impacts of community festivals, part 1: Item generation and purification of the measure, Event Management, 7: 11-24.

Doğan, H. Z. (2004). Turizmin Sosyo-Kültürel Temelleri. Ankara: Detay Yayıncllı.

Fredline, E., Jago, L. and Deery, M. (2003). The Development of a Generic Scale to Measure the Social Impacts of Events. Event Management, 8: 23-37.

Günlü, E. (2007). Turizm Sosyolojisi ve Turistik Tüketici Davranışları, (Editör) İçöz, O.: Genel Turizm - Turizmde Temel Kavramlar ve İlkeler içinde (ss. 167-182), Ankara: Turhan Kitabevi.

Helgadóttir, G. (2018). Herding Livestock and Managing People: The Cultural Sustainability of a Harvest Festival, (Editor) J. Mair: The Routledge Handbook of Festivals 1st Edition içinde (ss. 335-343), Routledge.

İçöz, O. (2001). Turizm İşletmelerinde Pazarlama, İlkeler ve Uygulamalar. Ankara: Turhan Kitabevi.

İçöz, O., Var, T. ve İlhan, İ. (2009). Turizm Planlaması ve Politikası - Turizmde Bölgesel Planlama. Ankara: Turhan Kitabevi.

İzmir Büyük Şehir Belediyesi (2019). Kültür http://kultursanat.izmir.bel.tr/Sayfalar/Sayfa/IzmirYarimadaEtkinlikleri (Erişim tarihi: 13.06.2019).

Kozak, N., Kozak, M. A. ve Kozak, M. (2008). Genel Turizm, İlkeler - Kavramlar (7 b.), Ankara: Detay Yayıncilı.

Kuban, D. (2000). Tarihi Çevre Korumanın Mimarlkk Boyutu: Kuram ve Uygulama, İstanbul: YEM Yayın. MacCannell, D. (1974). Staged Authenticity: Arrangements of Social Space in Tourist Settings. Sociological Abstracts, 22.

Mair, J. (2018). Introduction, (Editor) J. Mair: The Routledge Handbook of Festivals 1st Edition içinde (ss. 3-11), Routledge.

Mathieson, A. and Wall, G. (1982). Tourism: Economic, Physical and Social Impacts . Longman Pub Group.

McCool, S. F. (1996). Limits of Acceptable Change: A Framework for Managing National Protected Areas: Experiences from the United States. Workshop on Impact Management in Marine Parks. Kuala Lumpur, Malaysia: Maritime Institute of Malaysia.

McKercher, B. and Chow, S. (2001). Cultural distance and participation in cultural tourism. Pacific Tourism Review, 5(1): 23 - 32.

Olalı, H. (1990). Turizm Politikası ve Planlaması. İstanbul: İşletme Fakültesi Yayını.

Olalı, H. ve Timur, A. (1988). Turizm Ekonomisi. İzmir: Ofis Ticaret Matbaacılık.

Olalı, H., Nazilli, S., Kırcıoğlu, N. ve Sümer, M. (1983). Dış Tanıtım ve Turizm. Ankara: Türkiye İş Bankası Kültür Yayınları.

Pavlukovic, V., Armenski, T. and Alcantara-Pilar, J. M. (2017). Social Impacts of Music Festivals: Does Culture Impact Locals' Attitude toward Events in Serbia and Hungary? Tourism Management, 63: 4253.

Pedersen, A. (2002). Managing Tourism at World Heritage Sites: a Practical Manual for World Heritage Site Managers. Paris, France: UNESCO World Heritage Centre. 
Picard, D. and Robinson, M. (2006). Festivals, tourism and social change: Remaking worlds, channel view publications, Clevedon, England.

Sayarı, B. K. and Gün, T. (2018). Placemaking Betwixt and Between Festivals and Daily Life, (Editor) J. Mair.: The Routledge Handbook of Festivals 1st Edition içinde (ss. 373-383), Routledge.

Sert, A. N. (2017). Festivallerin Yerel Halk Üzerindeki Sosyal Etkileri: Beypazarı Örneği. Selçuk Üniversitesi Sosyal Bilimler Enstitüsü Dergisi, (38): 187-199.

Small, K. (2007). Social Dimensions of Community Festivals: An Application of Factor Analysis in The Development of The Social Impact Perception (SIP) Scale. Event Management, 11: 45-55.

Stankey, G. H., Cole, D. N., Lucas, R. C., Petersen, M. E. and Frissell, S. S. (1985). The Limits of Acceptable Change (LAC) System for Wilderness Planning . Ogden: United States Department of Agriculture Forest Service .

T.C. İzmir Valiliği (2019). İstatistiklerle İzmir. http://www.izmir.gov.tr/istatistiklerle-izmir (Erişim Tarihi: 12.06.2019).

T.C. Urla Kaymakamlığ1 (2019). Tarihi ve coğrafi bilgiler. http://www.urla.gov.tr/tarihi-ve-cografibilgiler (Erişim Tarihi: 12.06.2019).

Tuan, Y. (1974). Topophilia: A Study of Environmental Perception, Attitudes and Values. Englewood Cliffs, New Jersey: Prentice-Hall.

Urla Belediyesi (2019). Stratejik Plan 2015-2019. http://www.urla.bel.tr/Sayfa/26/stratejik-plan-20152019 (Erişim Tarihi: 12.06.2019).

Usta, Ö. (2001). Genel Turizm. İzmir: Anadolu Matbaacilık.

Wilmersdörffer, R., and Schlicher, D. (2018). Evaluating the sociocultural effects of festivals: developing a comprehensive impact correlation model and its application, (Editor) J. Mair.: The Routledge Handbook of Festivals 1st Edition içinde (ss. 66-70), Routledge.

WTO. (1997). Agenda 21 for the Travel and Tourism Industry. WTO. doi:978-92-844-0371-4

Yıldırım, A. ve Şimşek, H. (2005). Sosyal Bilimlerde Nitel Araştırma Yöntemleri. Ankara: Seçkin Yayıncilik.

Yılmaz, B. S. (2007). Turizmin Sosyo-Ekonomik, Sosyo-Kültürel ve Çevresel Etkileri, (Editör) İçöz, O.: Genel Turizm - Turizmde Temel Kavramlar ve Ilkeler içinde (ss. 183-200), Ankara: Turhan Kitabevi.

Yolal, M., Gürsoy, D., Uysal, M., Kim, H.L. and Karacaoğlu, S. (2016). Impacts of Festivals and Events on Residents' Well-being. Annals of Tourism Research, (61): 1-18. 
EK1: Festivallerin Sosyal Etkilerine İlişkin İçerik Analizi Bulguları

\begin{tabular}{|c|c|c|c|c|c|c|c|c|c|c|c|c|c|c|c|c|c|c|c|c|c|c|c|c|c|c|c|c|c|c|c|c|c|c|c|}
\hline & Katılımcilar & Frek. & $\%$ & K1 & K2 & K3 & K4 & K5 & K6 & K7 & K8 & K9 & K10 & K11 & K12 & K13 & K14 & K15 & K16 & K17 & K18 & K19 & K20 & K21 & K22 & K23 & K24 & K25 & K26 & K27 & K28 & K29 & K30 & K31 & K32 \\
\hline & 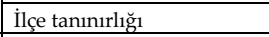 & 64 & 11,28 & 2 & 2 & 2 & \begin{tabular}{|l|}
2 \\
\end{tabular} & 2 & 2 & 2 & 2 & 2 & 2 & 2 & 2 & 2 & 2 & 2 & 2 & 2 & 2 & 2 & 2 & 2 & 2 & 2 & 2 & 2 & 2 & 2 & 2 & 2 & 2 & 2 & 2 \\
\hline 2. & Trafik sıkışıklığ1 & 56 & 9,87 & 3 & 2 & 2 & 1 & 1 & 2 & 2 & 3 & 2 & 1 & 2 & 1 & 2 & 2 & 2 & 3 & 3 & 2 & 1 & 2 & 2 & 1 & 1 & 1 & 1 & 1 & 2 & 1 & 1 & 2 & 2 & 2 \\
\hline 3. & Çöpler & 51 & 8,99 & 2 & 2 & 3 & 2 & 1 & 2 & 2 & 3 & 2 & 1 & 2 & 2 & 1 & 1 & 1 & 2 & 2 & 1 & 2 & 1 & 1 & 1 & 2 & 1 & 2 & 1 & 1 & 2 & 1 & 2 & 1 & 1 \\
\hline 4. & Kalabalık & 49 & 8,64 & 2 & 2 & 1 & 2 & 1 & 2 & 22 & 22 & 2 & 1 & 1 & 2 & 1 & 2 & 2 & 1 & 1 & 1 & 3 & 2 & 2 & 1 & 1 & 1 & 1 & 2 & 1 & 2 & 1 & 1 & 1 & 2 \\
\hline 5. & Gürülttü & 49 & 8,64 & 1 & 1 & 2 & \begin{tabular}{|l|}
2 \\
\end{tabular} & 1 & 2 & 1 & 3 & 2 & 3 & 1 & 2 & 1 & 2 & 1 & 1 & 1 & 1 & 2 & 1 & 1 & 1 & 1 & 2 & 1 & 2 & 2 & 2 & 1 & 2 & 2 & 1 \\
\hline 6. & $\begin{array}{l}\text { İlçede yaşanan ekonomik } \\
\text { canllıık }\end{array}$ & 47 & 8,28 & 2 & 1 & 2 & 1 & 1 & 1 & 2 & 1 & 1 & 2 & 1 & 1 & 1 & 1 & 1 & 2 & 1 & 1 & 3 & 1 & 3 & 1 & 2 & 2 & 2 & 2 & 1 & 1 & 1 & 2 & 2 & 1 \\
\hline 7. & İlçe imaj1 & 37 & 6,52 & 1 & 2 & 1 & \begin{tabular}{|l|}
1 \\
\end{tabular} & 1 & 2 & 3 & \begin{tabular}{|l|}
1 \\
\end{tabular} & 2 & 1 & 1 & 1 & 0 & 0 & 2 & 0 & 1 & 0 & 1 & 2 & 2 & 0 & 0 & 0 & 2 & 2 & 3 & 1 & 1 & 1 & 1 & 1 \\
\hline 8. & $\begin{array}{l}\text { İlçede yaşanan hareketlilik, } \\
\text { canlılık }\end{array}$ & 30 & 5,29 & 1 & 1 & 1 & 1 & 1 & 0 & 1 & 1 & 0 & 1 & 2 & 1 & 1 & 2 & 3 & 0 & 1 & 1 & 2 & 1 & 0 & 1 & 1 & 0 & 1 & 0 & 1 & 1 & 0 & 1 & 1 & 1 \\
\hline 9. & Karmaşa & 27 & 4,76 & 1 & 2 & 1 & \begin{tabular}{|l|}
1 \\
\end{tabular} & 2 & 0 & 1 & 0 & 0 & 1 & 0 & 3 & 1 & 0 & 0 & 1 & 0 & 0 & 3 & 1 & 2 & 1 & 1 & 0 & 0 & 1 & 2 & 0 & 0 & 0 & 2 & 0 \\
\hline 10. & $\begin{array}{l}\text { İlçe halkının ekonomiye } \\
\text { katılması }\end{array}$ & 26 & 4,58 & 1 & 2 & 1 & 1 & 0 & 2 & 1 & 1 & 1 & 2 & 1 & 0 & 0 & 1 & 2 & 0 & 0 & 0 & 1 & 1 & 1 & 2 & 0 & 1 & 0 & 0 & 1 & 1 & 0 & 1 & 1 & 0 \\
\hline 11. & \begin{tabular}{|l|} 
Ulaşım \\
\end{tabular} & 23 & 4,05 & 1 & 1 & 1 & \begin{tabular}{|l|}
1 \\
\end{tabular} & 0 & 0 & \begin{tabular}{|l|}
1 \\
\end{tabular} & $\begin{array}{ll}1 \\
\end{array}$ & 0 & 1 & 1 & 0 & 1 & 1 & 1 & 0 & 1 & 1 & 1 & 0 & 1 & 0 & 1 & 0 & 1 & 1 & 0 & 1 & 1 & 1 & 1 & 1 \\
\hline 12. & \begin{tabular}{|l|} 
İlçe halkının ilçesini \\
geliştirmesinde motive \\
olması
\end{tabular} & 22 & 3,88 & 1 & 1 & 0 & 1 & 0 & 1 & 0 & 0 & 1 & 0 & 0 & 1 & 1 & 2 & 1 & 2 & 0 & 0 & 1 & 0 & 0 & 1 & 2 & 1 & 0 & 1 & 0 & 0 & 1 & 1 & 1 & 1 \\
\hline 13. & Kültürlerle kaynaşma & 19 & 3,35 & 1 & 1 & 1 & 2 & 1 & 0 & 1 & 0 & 1 & 0 & 1 & 2 & 0 & 1 & 0 & 0 & 0 & 0 & 1 & 1 & 1 & 0 & 0 & 1 & 0 & 1 & 0 & 0 & 0 & 1 & 1 & 0 \\
\hline 14. & Yeni İnsanlar tanıma & 18 & 3,17 & 1 & 1 & 2 & 1 & 1 & 0 & 1 & 0 & 1 & 0 & 1 & 2 & 0 & 1 & 0 & 0 & 0 & 0 & 1 & 1 & 1 & 0 & 0 & 1 & 0 & 0 & 0 & 0 & 0 & 2 & 0 & 0 \\
\hline 15. & $\begin{array}{l}\text { İlçe halkının düzenlemeye } \\
\text { katılımı, yeni beceriler } \\
\text { edinme }\end{array}$ & 17 & 2,99 & 1 & 1 & 0 & 1 & 0 & 2 & 0 & 0 & 1 & 1 & 2 & 0 & 0 & 1 & 1 & 0 & 1 & 0 & 3 & 0 & 0 & 0 & 0 & 1 & 0 & 0 & 0 & 0 & 0 & 1 & 0 & 0 \\
\hline 16. & $\begin{array}{l}\text { İlçe halkının ilçeye } \\
\text { bağllı̆ı̆ının artması }\end{array}$ & 17 & 2,99 & 0 & 1 & 0 & 1 & 0 & 2 & 0 & 0 & 1 & 1 & 0 & 0 & 1 & 1 & 1 & 0 & 1 & 1 & 1 & 0 & 0 & 0 & 1 & 2 & 0 & 0 & 0 & 0 & 0 & 2 & 0 & 0 \\
\hline 17. & Suç oranı & 15 & 2,64 & 1 & 1 & 0 & 0 & 1 & 2 & 0 & 0 & 1 & 0 & 0 & 0 & 1 & 1 & 0 & 0 & 1 & 0 & 1 & 1 & 0 & 0 & 1 & 1 & 0 & 1 & 0 & 0 & 0 & 1 & 0 & 0 \\
\hline & Toplam & 567 & 100 & & & & & & & & & & & & & & & & & & & & & & & & & & & & & & & & \\
\hline
\end{tabular}

